\title{
Is Exaggerated Release of Arginine Vasopressin an Endocrine Disorder? Pathophysiology and Treatment
}

\author{
San-e Ishikawa \\ Department of Endocrinology and Metabolism, International University of Health and Welfare Hospital, \\ Nasushiobara 329-2763, Tochigi, Japan; saneiskw@jichi.ac.jp; Tel.: +81-287-39-3060 \\ Academic Editor: Lindsay Brown \\ Received: 2 October 2017; Accepted: 30 October 2017; Published: 31 October 2017
}

\begin{abstract}
Exaggerated release of arginine vasopressin (AVP) is profoundly involved in impaired water excretion and related hyponatremia. Such disorders underlie syndromes of inappropriate secretion of antidiuretic hormone (SIADH) and edematous diseases, such as congestive heart failure and decompensated liver cirrhosis. All the causes are fundamentally from non-endocrine diseases. AVP-induced water retention could produce hyponatremia, and further accelerate poor long-term outcome of edematous diseases. Administration of AVP $V_{2}$ receptor antagonists verifies how much AVP is involved in the pathogenesis of the impaired water excretion. The present paper demonstrated that exaggerated release of AVP plays a crucial role as an accessory endocrine disorder in pathological states of water retention and dilutional hyponatremia in non-endocrine disorders.
\end{abstract}

Keywords: impaired water excretion; hyponatremia; aquaporin 2; arterial underfilling; heart failure; $\mathrm{SIADH}$; vasopressin (AVP) $\mathrm{V}_{2}$ receptor antagonist

\section{Introduction}

Endocrine disorders are fundamentally dependent upon the disorders of endocrine glands and their hormonal receptors. Regarding arginine vasopressin (AVP), three disorders are listed as endocrine diseases, namely, central and nephrogenic diabetes insipidus, and syndrome of inappropriate secretion of antidiuretic hormone (SIADH). Persistently inappropriate secretion of AVP produces impaired water excretion and hyponatremia in SIADH. However, there is no evidence of the disorders of endocrine glands in SIADH. SIADH include disorders of the central nervous system, intrathoracic disorders and drug administration, in addition to ectopic production of AVP in cancer tissues. Therefore, we do not know if SIADH is truly an endocrine disease. If we consider it from a different point of view, we can widen the category of disorders which are associated with exaggerated release of AVP. If so, we can include all disorders that have augmented release of AVP, even if their original diseases belong to non-endocrine organs.

Exaggerated release of AVP is profoundly linked to the development of water retention and edema in edematous diseases, including congestive heart failure (CHF) and decompensated liver cirrhosis $[1,2]$. Recently, it has been evident that $A V P V_{2}$ receptor antagonists are effective in decelerating circulatory blood volume expansion and related dilutional hyponatremia in SIADH and CHF [3-5]. This could precede the category of exaggerated secretion of AVP in non-endocrine disorders as a sub-endocrinological disorder. In the present review, I note the pathophysiological state of excessive $\mathrm{AVP}$ secretion and possible treatments with $\mathrm{AVP} \mathrm{V}_{2}$ receptor antagonists in various diseases. 


\section{Clinical Causes of Inappropriate Secretion of AVP}

In some pathological states, release of AVP is persistently elevated although there is normal or increased circulatory blood volume. Such an augmented AVP release is "inappropriate", thus providing impaired water excretion. Pathological states of water retention could develop dilutional hyponatremia, because extracellular sodium $(\mathrm{Na})$ content remains unchanged, and the extracellular volume increases excessively. Namely, inappropriate secretion of AVP is in concert with pathological states of hyponatremia. As shown in Figure 1, there are three types of hyponatremia, depending on extracellular $\mathrm{Na}$ and extracellular volume. Hyponatremia accompanied by circulatory volume expansion (hypervolemic or dilutional hyponatremia, Figure 1C) is found in edematous diseases, including congestive heart failure, liver cirrhosis with ascites and nephrotic syndrome. The renin-angiotensin-aldosterone system and sympathetic nervous system, as well as AVP, are all mediated through arterial baroreceptors [1,6]. This mechanism is discussed in detail later. The second type is hyponatremia accompanyied by euvolemic state (euvolemic hyponatremia, Figure 1B). Such impairment in water excretion is found in SIADH, hypopituitarism, hypothyroidism and other disorders. The causes of SIADH are listed in Table 1. The diseases are not related to endocrine diseases or neurohypophyseal disorders.

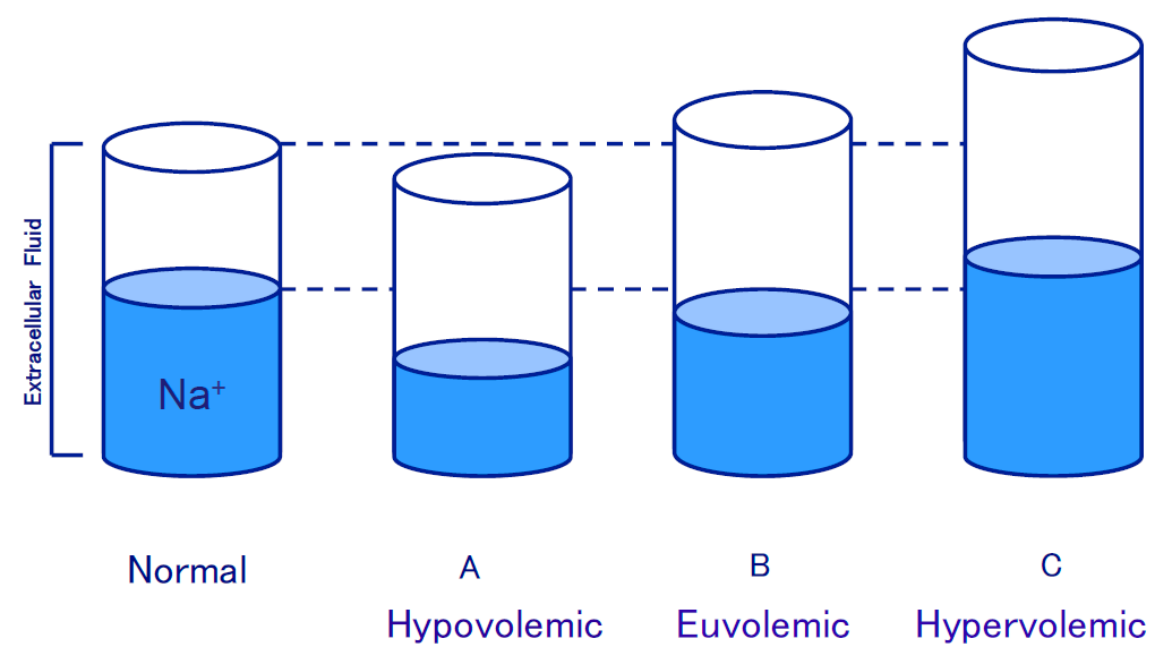

Figure 1. Three types of hyponatremia. (A) Hypovolemic hyponatremia; (B) Euvolemic hyponatremia; (C) Hypervolemic hyponatremia.

In contrast, AVP is physiologically released under circulatory blood volume depletion. This is a homeostatic response, and the elevation of AVP release autonomically ceases after the circulatory blood volume returns to normal levels (Figure 1A).

Table 1. Causes of SIADH.

\begin{tabular}{cccc}
\hline Cancer & Diseases of Central Nervous System & Intrathoracic Diseases & Drugs \\
\hline Lung cancer & Encephalils & Pneumonia & Vincristine \\
\hline Duodenal cancer & Meningitis & Tuberculosis & Cyclophosphamide \\
\hline Pancreatic cancer & $\begin{array}{c}\text { Cerebrovascular diseases } \\
\text { (Cerebral infarction and hemorrhage) }\end{array}$ & Pulmonary abscess & Clofiblate \\
\hline Malignant lymphoma & Subarachnoid hemorrhage & Pulmonary fungus diseases & Carbamazepine \\
\hline Prostatic cancer & Subdural hematoma & $\begin{array}{c}\text { Lung cancer (non-ectopic } \\
\text { production) }\end{array}$ & Nicotine \\
\hline \multirow{2}{*}{ Ewing sarcoma } & Head injury & & \\
\cline { 2 - 4 } & Acute porphyria & & \\
\cline { 2 - 4 } & Pituitary tumor & & \\
\hline
\end{tabular}




\section{Pathogenesis of Exaggerated AVP Release}

\subsection{Edematous Diseases}

Renal $\mathrm{Na}$ and water excretion are predominantly regulated by the integrity of arterial circulation, that is they are determined by cardiac output and peripheral vascular resistance. Several baroreceptors on the high pressure side of the circulation can sense arterial underfilling. They are located in the carotid sinus, left atrium, aortic arch and renal afferent arterioles. Reduction of baroreceptor sensitivity could relieve the "tonic inhibition" on the afferent vagal nerve pathway of hormonal synthesis and secretion by the hypothalamo-neurohypophyseal system [7-11]. Such a reduction occurs when there is a reduction in systemic arterial pressure, cardiac stroke volume, renal perfusion or peripheral vascular resistance. In congestive heart failure, cardiac output is decreased following reduced stroke volume, though there is an increase in total circulatory blood volume. Low cardiac output could promote a decrease in "effective circulatory blood volume", and impairs the sensitivity of baroreceptors. A reduction in effective circulatory blood volume is closely related to increases in the activity of the sympathetic nervous system, activation of the renin-angiotensin-aldosterone system and non-osmotic release of AVP. However, it remains unclear how baroreceptors sense the decrease in effective circulatory blood volume linked to low cardiac output in heart failure.

In decompensated liver cirrhosis, the pathogenesis of non-osmotic release of AVP is similar to that in heart failure. Peripheral arterial vasodilatation and arterio-venous fistula, primarily in the splanchinic vascular beds, have been proposed to account for the reduction in effective circulatory blood volume [12]. Such a phenomenon could reduce baroreceptor sensitivity, thus providing relief of tonic inhibition on hormonal secretion. Plasma AVP levels are persistently elevated with augmented expression of AVP mRNA in the hypothalamus in liver cirrhosis [13,14], and its elevation is further manifested in decompensated cirrhosis as compared to compensated cirrhosis. Furthermore, activation of the renin-angiotensin-aldosterone system and the sympathetic nervous system occur in cirrhosis, and the degree of activation is correlated with the progression of cirrhotic decompensation [15].

In edematous diseases, impaired water excretion is frequently linked to exaggeration of non-osmotic AVP release. The activation is mediated through baroreceptors, whose sensitivity is blunted under "arterial underfilling". In addition, both the sympathetic nervous system and the renin-angiotensin-aldosterone system are activated, and increase Na reabsorption, followed by an increase in water retention. Because edematous diseases of heart failure and liver cirrhosis have excessive body water, these hormonal responses could be "inappropriate" and result in developing water retention.

\subsection{SIADH}

In patients with SIADH, plasma AVP is persistently elevated despite hypoosmolality. This is because AVP secretion is not suppressed inappropriately under hypotonic conditions, in which AVP release is reduced to undetectable levels in normal subjects [16]. There are two sources of AVP in SIADH: ectopic production of AVP in lung, pancreatic and other cancers, and increased central secretion of AVP from the hypothalamo-neurohypophyseal system due to central nervous system disorders, intrathoracic disorders or drugs. Normal values of plasma AVP are frequently observed in SIADH patients; these plasma AVP concentrations, however, are increased with respect to low plasma osmolality.

Ectopic production of AVP is clear, because AVP is ectopically synthesized in several cancer tissues and directly released into the systemic circulation. The produced AVP is biologically active. In contrast, there is no evidence regarding how afferent pathways transduce the stimulatory signals to AVP neurons in hypothalamus in central nervous system and lung disorders. In part, a possible mediator maybe vasospasm of central brain arteries in the disorders of subarachnoid hemorrhage. Disruption of extracranial vascular aneurysms may be involved in triggering AVP release 
from the hypothalamo-neurohypophyseal system [17]. However, the signal and its pathways are still unknown.

Hypothalamic AVP neurons are passively activated through stimulatory signals from the disorders of non-endocrine organs and tissues, thus providing an increase in endogenous AVP release in SIADH. This enhanced AVP release is a time-limited phenomenon, except for ectopic production of AVP.

\section{Impaired Water Excretion}

Several studies in animal models of impaired water excretion have shown that enhanced hydro-osmotic action of AVP depends on non-suppressible release of AVP. In an experimental model of SIADH in rats, serum Na levels decreased to below $120 \mathrm{mmol} / \mathrm{L}$ within $24 \mathrm{~h}$, and hyponatremia persisted during a 14-day observation period. This animal model was made by the subcutaneous administration of the AVP $V_{2}$ agonist, 1-deamino-8-D-arginine vasopressin (DDAVP), by an osmotic mini pump, and offering a liquid diet [18]. Aquaporin 2 (AQP2) is an AVP-dependent water channel of collecting duct cells [19]. Receptor occupancy with AVP in the renal collecting duct allows the activation of adenylate cyclase to produce cAMP. cAMP activates cAMP-dependent protein kinase A (PKA), and phosphorylation of PKA then mediates cellular signaling of AVP to the AQP2 water channel. This leads to translocation of AQP2 from membranes of cytoplasmic vesicles to the apical plasma membrane (short-term regulation), and increases AQP2 transcription and protein synthesis (long-term regulation). The expression of AQP2 mRNA was upregulated throughout the 14-day observation period. The peak of mRNA expression occurred at day 2 , and was followed by a gradual decrease thereafter [20,21]. The increase in AQP2 mRNA expression was reversed three hours after oral administration of the non-peptide AVP $V_{2}$ receptor antagonist OPC-31260. The mRNA results were paralleled by changes in AQP2 protein expression [20,21].

An experimental rat model of liver cirrhosis with ascites was made by the subcutaneous administration of carbon tetrachloride $\left(\mathrm{CCl}_{4}\right)$ for three months. AQP2 mRNA and protein expression were increased in these cirrhotic rats [20]. An acute water load clarified the impairment in renal water excretion, a finding associated with the non-suppressible release of AVP. The administration of OPC-31260 totally reversed the increase in AQP2 mRNA expression.

Increases in AQP2 mRNA expression and protein abundance were found in experimental models of congestive heart failure in rats. $\mathrm{Xu}$ et al. [22] stimulated chronic heart failure by ligating the descending limb of the left coronary artery. Cardiac output and plasma osmolality were significantly decreased, and plasma AVP increased in the chronic heart failure rat models compared to the sham-operated rats. AQP2 mRNA and protein abundance were both significantly increased in the kidneys of chronic heart failure rats. Similarly, Nielsen et al. [23] showed enhanced trafficking of AQP2 to the apical plasma membrane in collecting ducts of rats with congestive heart failure. Administration of OPC-31260 significantly reduced AQP2 mRNA expression and protein abundance.

In edematous diseases of congestive heart failure and liver cirrhosis with ascites, exaggerated release of AVP is persistent under arterial underfilling [1,2,7]. Continuous baroreceptor-mediated AVP release further impairs renal water excretion in the state of water retention, contributing to acceleration of edematous change. Also, the activation of the renin-angiotensin-aldosterone and sympathetic nervous systems produce renal Na reabsorption, thus providing water retention secondarily (Figure 2). These synergistic changes of baroreceptor-mediated hormonal activation under arterial underfilling, which reduce renal water reabsorption, may not take place in edematous diseases. Taken together, the hypervolemic state is pathologically maintained throughout edematous diseases.

In contrast, circulatory blood volume is different in SIADH. Initially, elevation of plasma AVP levels increase renal water reabsorption and produce a hypervolemic state. Thereafter, the body moves gradually to an euvolemic steady state. This change is derived from "AVP escape", and an increase in renal Na excretion. Sustained elevation of AVP release produces downregulation of receptor binding capacity of AVP $\mathrm{V}_{2}$ receptors in the collecting duct, but cellular signaling of AVP remains augmented. In response to this signal, expression of AQP2 mRNA and protein abundance are 
increased, and produce sustained elevation of water reabsorption. Prompt increase in extracellular fluid dilutes it because of no change in Na content, and there is a shift to a hypotonic condition, which partially diminishes the augmented expression of AQP2 mRNA and protein abundance as described earlier in the animal model of SIADH [21,24]. Therefore, maximal urinary concentration is partially decelerated, followed by an increase in urine volume. In the steady state extracellular volume gradually decreases toward a normal volume, moving away from the initial volume expansion.

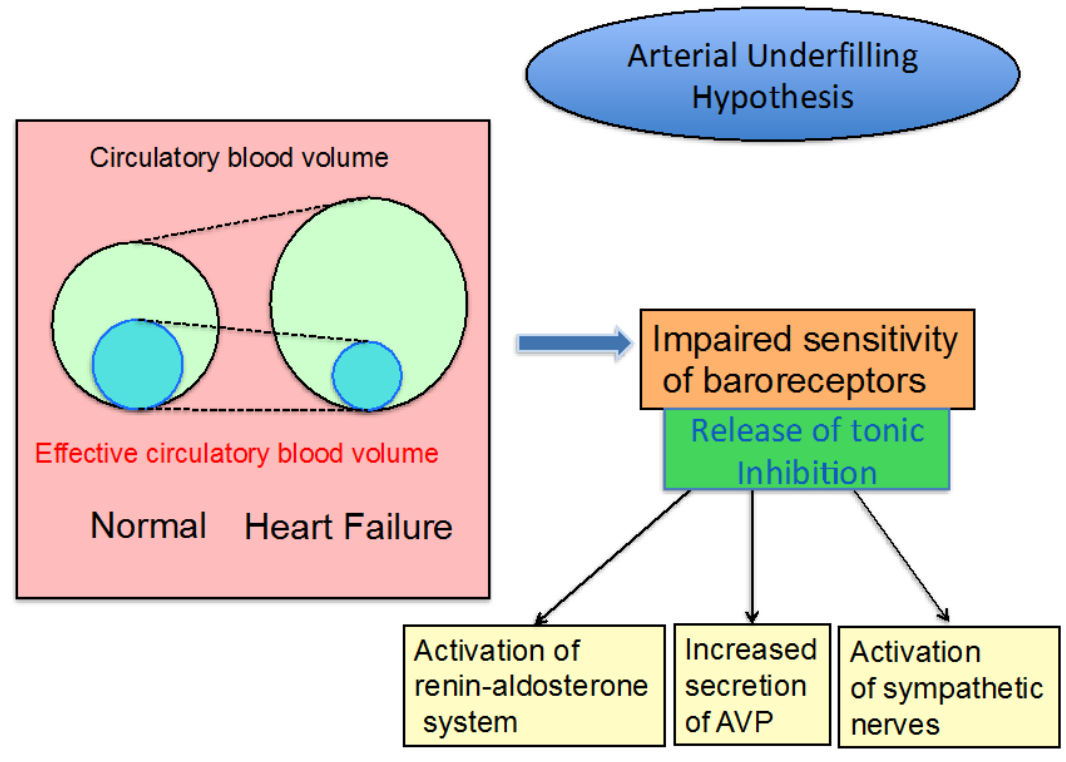

Figure 2. Hypothesis for dysregulation of baroreceptor-mediated hormonal release in congestive heart failure.

In SIADH, Na metabolism also contributes to decrease circulatory blood volume. Increased circulatory blood volume allows an increment in renal blood flow, which modulates renal Na handling. These results in enhanced glomerular filtration, inhibition of the renin-angiotensin-aldosterone system, augmented secretion of natriuretic peptide, and increases in renal prostaglandin synthesis and the kinin-kallikrein system. These alterations all enhance renal $\mathrm{Na}$ excretion, resulting in an increase in renal water excretion. The compensation in water and $\mathrm{Na}$ metabolism contribute to reduce the increased circulatory blood volume, and produce a new steady "euvolemic" state. Such alterative changes do not occur in edematous diseases.

Urinary excretion of AQP2 (UAQP2) was detected in both soluble and membrane-bound forms by Western blot analysis [25]. Immunoblots of urine samples showed AQP2 with molecular sizes of $29 \mathrm{kDa}$ and $40-50 \mathrm{kDa}$. The band at 40-50 kDa represents a glycosylated form of the $29 \mathrm{kDa}$ protein. UAQP2 can be determined quantitatively by radioimmunoassays or ELISAs [26,27]. The fraction of AQP2 excreted into the urine is approximately 3\% of the AQP2 present in renal collecting duct cells [28]. We found positive correlation of UAQP2 with plasma AVP levels in normal subjects [26]. As shown in Figure 3, UAQP2 was markedly elevated in patients with SIADH, hypopituitarism, mineralocorticoid-responsive hyponatremia of the elderly (MRHE) and congestive heart failure $[29,30]$. In these disorders, plasma AVP levels were persistently increased. In contrast, UAQP2 was depressed in central diabetes insipidus, where AVP secretion is absent. Furthermore, we demonstrated that there was also a positive correlation between UAQP2 and plasma AVP levels in congestive heart failure [30]. Taken together, these findings suggest that elevation of UAQP2 is derived from the exaggerated hydroosmotic action of AVP in a pathological state of impaired water excretion. Measurement of UAQP2 is a useful tool for evaluating water metabolism disorders. 


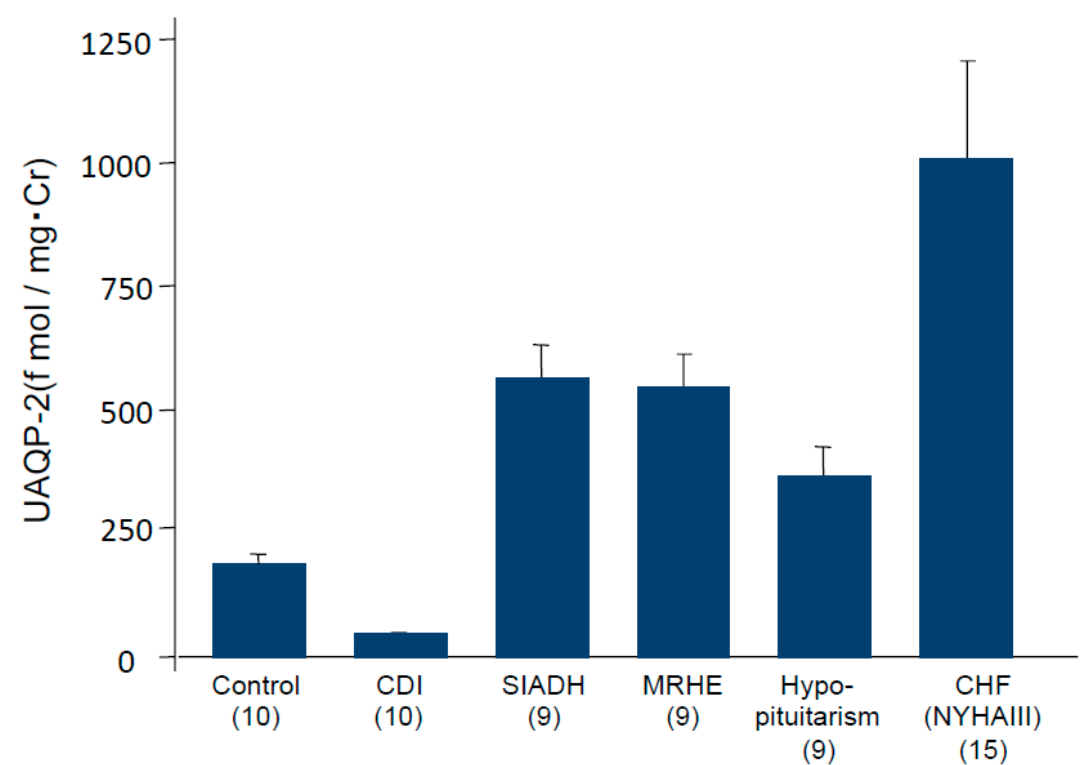

Figure 3. Elevation of urinary excretion of aquaporin 2 (UAQP2) in patients with impaired water excretion. The numbers of patients are shown in brackets.

\section{Hyponatremia Predicts Poor Prognosis}

Hyponatremia is relatively common in congestive heart failure. Gheorghiade et al. [31] reported that hyponatremia of less than $135 \mathrm{mmol} / \mathrm{L}$ was found in $19.7 \%$ of 48,612 patients. There are several reports regarding the relation of hyponatremia with prognosis in congestive heart failure. In the short-term, length of stay in hospital and in-hospital mortality were greater in patients having less than $135 \mathrm{mmol} / \mathrm{L}$ hyponatremia than those with hyponatremia greater than $135 \mathrm{mmol} / \mathrm{L}$ [31]. We reported that hyponatremia predicts long-term prognosis in heart failure patients receiving cardiac resynchronization therapy (CRT) [32]. Seventy-seven patients who were all in NYHA II, III or IV classes, and their left ventricular ejection fraction on echocardiogram was less than $35 \%$, were examined. During a mean follow-up period of 601 days, 22 of 77 patients (29\%) had a cardiovascular event. In multiple analysis, hyponatremia was the only independent factor associated with the occurrence of heart failure rehospitalization and cardiac death (Hazard ratio 0.82, $p=0.034$ ). Similar results were obtained in other studies [33,34]. Low serum $\mathrm{Na}$ levels at admission were closely associated with increased post-discharge mortality and rehospitalization in patients with heart failure. Dilutional hyponatremia is a consequence of persistent AVP-induced water retention due to "arterial underfilling", as described earlier. Simultaneous circulatory blood volume expansion, in association with hyponatremia, could increase cardiac preload, thus accelerating dysfunction of cardiac contraction in heart failure (vicious cycle) [7,35].

Similarly, hyponatremia is found in decompensated cirrhosis [12,13]. As mentioned above, baroreceptor-mediated hormonal activation promotes water and Na retention in cirrhosis with ascites under arterial underfilling. Post-discharge mortality is increased when hyponatremia becomes manifested [36-38]. Several reports found that survival rates progressively decreased to below $40 \%$ within 3-6 months if serum Na levels were $130 \mathrm{mmol} / \mathrm{L}$ or less. Thus, occurrence of hyponatremia reflects serious condition in cirrhotic patients with ascites. This hypervolemic hyponatremia is also based on an inappropriate increase in body fluid.

Euvolemic hyponatremia is a hallmark of SIADH. There is no report that hyponatremia may affect prognosis in SIADH in the literature.

\section{AVP $V_{2}$ Receptor Antagonists and Impaired Water Excretion}

As aforementioned, we have demonstrated that exaggerated release of AVP results in impaired water excretion. Therapeutic approaches for blocking the antidiuretic action could ameliorate 
an inappropriate increase in body fluid. Now, such a therapy is possible, because non-peptide AVP $\mathrm{V}_{2}$ receptor antagonists can be clinically available to patients [39,40].

We observed the diuretic effects of $A V P \mathrm{~V}_{2}$ receptor antagonist in experimental SIADH rats [41]. The SIADH rat model was made by the subcutaneous administration of the $\mathrm{V}_{2}$ agonist, DDAVP, by osmotic minipumps, and offering a liquid diet. Serum Na levels were decreased to below $120 \mathrm{mmol} / \mathrm{L}$ within $24 \mathrm{~h}$, and hyponatremia was maintained in association with a concentrated urine throughout the 14-day observation period. The oral administration of the non-peptide AVP $\mathrm{V}_{2}$ receptor antagonist OPC-31260 started on day 7, and continued once a day for the duration of the experiment. This maneuver promptly normalized serum Na levels in $12 \mathrm{~h}$, in association with an increase in urine volume and a decrease in urinary osmolality. The normalization of serum the Na level was maintained during the rest of the experimental period.

The administration of carbon tetrachloride $\left(\mathrm{CCl}_{4}\right)$ for three months produced liver cirrhosis with ascites in rats. Non-suppressible release of AVP was obtained in the $\mathrm{CCl}_{4}$-induced cirrhotic rats. An acute water load $(30 \mathrm{~mL} / \mathrm{kg})$ verified a reduction in percent changes of excreted water, and an increase in urinary osmolality in cirrhotic rats as compared to normal rats. Such impaired water excretion was totally improved by orally administering OPC-31260 [42]. These in vivo experiments demonstrate that the impaired water excretion associated with non-suppressible AVP release can be reversed.

We have previously demonstrated the efficacy of mozavaptan (OPC-31260) in hyponatremia in patients with SIADH [43]. A single intravenous injection of mozavaptan increased urine volume and decreased urinary osmolality, providing a $3 \mathrm{mmol} / \mathrm{L}$ increase in serum $\mathrm{Na}$ levels during the 4-h observation period. Schrier et al. [3] reported study of ascending levels of Tolvaptan in Hyponatremia (SALT)-1 and SALT-2 studies in the United States and Europe. They studied the efficacy of tolvaptan in hyponatremic patients, including SIADH, liver cirrhosis and congestive heart failure. In the tolvaptan group, serum Na levels were $128.5 \pm 4.5 \mathrm{mmol} / \mathrm{L}$. After administering tolvaptan, serum Na levels normalized during the 30-days observation period. Serum Na levels increased by $3.7 \pm 2.7 \mathrm{mmol} / \mathrm{L}$ at four days, and by $6.2 \pm 4.1 \mathrm{mmol} / \mathrm{L}$ at 30 days. In contrast, serum $\mathrm{Na}$ levels remained unchanged during the 30-day observation period in the placebo group. The efficacy of tolvaptan was mostly observed in the subgroup of SIADH patients. Berl et al. [44] observed 111 patients who were part the SALT study. After completing the SALT study, these 111 patients had been treated with tolvaptan for an additional four years. Serum Na levels were continuously kept within the normal range during the four-year observation period (SALTWATER study).

Gheorghiade et al. [45] demonstrated that tolvaptan increased diuresis in patients with congestive heart failure. Oral administration of tolvaptan increased urine volume, reduced body weight and increased serum Na levels in heart failure patients with NYHA classes I and II. Similar results were also obtained in advanced heart failure patients with NYHA classes III and IV [4]. Konstam and his associates [5] studied 4133 patients with congestive heart failure in 359 institutes in the United States (EVEREST study). Then mean follow-up period was 9.9 months. In the short-term, clinical symptoms of dyspnea, orthopnea, fatigue and edema were markedly improved in the tolvaptan group compared to the placebo group [46]. The patients who had greater reduction in body weight also had greater water diuresis, improved clinical symptoms and shortened in-hospitalization. In the long-term, there was a significantly greater decrease in body weight and increase in serum $\mathrm{Na}$ levels in the tolvaptan group compared to the placebo group. However, Kaplan-Meyer analysis observed no difference in cardiac death and rehospitalization of heart failure between the tolvaptan and the placebo groups [5].

In Japan, tolvaptan has been clinically available for treating congestive heart failure [47]. Tolvaptan is effective for increasing water diuresis, thus resulting in rapid reduction of congestion. However, clinical experience has clarified that approximately $20-40 \%$ of patients fail to respond to tolvaptan, and that they had little alteration in urine volume and urinary osmolality $[48,49]$. We now recognize that there are two groups: responders and the non-responders. At the present time, the mechanism that underlies the unresponsiveness to tolvaptan is not understood. It has been about six years 
since tolvaptan has been used for treating heart failure in Japan. There are a few reports evaluating the long-term outcome of heart failure. Uemura et al. [50] documented that tolvaptan significantly reduced cardiac mortality and re-hospitalization of heart failure patients, but did not modify the survival rate in 102 patients with congestive heart failure. On the other hand, Matsue et al. [51] reported that there was no change in the long-term outcome after tolvaptan treatment in 217 patients with acute heart failure. Their additional analysis revealed that tolvaptan improved combined events of heart failure re-hospitalization and all-cause death, in patients with eGFR of $30 \mathrm{~mL} / \mathrm{min} / 1.73 \mathrm{~m}^{2}$ or above. Further studies will be necessary to exactly determine whether tolvaptan affects long-term outcomes in patients with heart failure.

The aforementioned SALT study included cirrhotic patients who accounted for one third of the hyponatremic patients [3]. Serum Na levels significantly increased in association with water diuresis. Several groups reported that tolvaptan increased serum $\mathrm{Na}$ levels in decompensated cirrhotic patients [52,53]. A clinical trial study was performed in 164 cirrhotic patients with ascites in Japan [54]. The tolvaptan group (82 patients) increased water diuresis and serum $\mathrm{Na}$ levels by about 2-6 mmol/L, compared to the placebo group which had no change in water diuresis.

\section{Conclusions}

In this review, I have demonstrated that exaggerated release of AVP is profoundly involved in impaired water excretion in edematous diseases, as well as in SIADH. All the causes are fundamentally from non-endocrine disorders. Administration of $A V P V_{2}$ receptor antagonists provides evidence that AVP directly enhances water retention, and demonstrates AVP involvement in the pathogenesis of impaired water excretion. These findings indicate that exaggerated release of AVP plays a crucial role as an accessory endocrine disorder in pathological states of water retention and related dilutional hyponatremia in non-endocrine disorders.

Conflicts of Interest: The author declares no conflict of interest.

\section{References}

1. Schrier, R.W. Pathogenesis of sodium and water retention in high-output and low-output cardiac failure, nephrotic syndrome, cirrhosis and pregnancy. N. Engl. J. Med. 1988, 319, 1065-1072. [CrossRef] [PubMed]

2. Schrier, R.W. Pathogenesis of sodium and water retention in high-output and low-output cardiac failure, nephrotic syndrome, cirrhosis and pregnancy (2). N. Engl. J. Med. 1988, 319, 1127-1134. [CrossRef] [PubMed]

3. Schrier, R.W.; Gross, P.; Gheroghiade, M.; Berl, T.; Verbalis, J.G.; Czerwiec, F.S.; Orlandi, C.; For the SALT Investigators. Tolvaptan, a selective oral vasopressin $\mathrm{V}_{2}$-receptor antagonist, for hyponatremia. N. Engl. J. Med. 2006, 355, 2099-2112. [CrossRef] [PubMed]

4. Gheroghiade, M.; Gattis, W.A.; O'Connor, C.M.; Adams, K.F.; Elkayam, U.; Barbagelata, A.; Ghali, K.; Benka, R.I.; McGrew, F.A.; Klapholz, M.; et al. Effect of tolvaptan, a vasopressin antagonist, in patients hospitalized with worsening heart failure: A randomized controlled trial. JAMA 2004, 291, 1963-1971. [CrossRef] [PubMed]

5. Konstam, M.A.; Gheroghiade, M.; Burnett, J.C., Jr.; Grinfeld, L.; Maggioni, A.P.; Swedberg, K.; Udelson, J.E.; Zannad, F.; Cook, T.; Ouyang, J.; et al. Effects of oral tolvaptan in patients hospitalized for worsening heart failure: The EVEREST Trial. JAMA 2007, 297, 1319-1331. [CrossRef] [PubMed]

6. Ishikawa, S.; Schrier, R.W. Pathophysiological roles of arginine vasopressin and aquaporin-2 in impaired water excretion. Clin. Endocrinol. 2003, 58, 1-17. [CrossRef]

7. Schrier, R.W.; Abraham, W. Hormone and hemodynamics in heart failure. N. Engl. J. Med. 1999, 341, 577-585. [CrossRef] [PubMed]

8. Szatalovitz, V.L.; Arnold, P.E.; Chaimovitz, C.; Bichet, D.G.; Berl, T.; Schrier, R.W. Radioimmunoassay of plasma arginine vasopressin in hyponatremic patients with congestive heart failure. N. Engl. J. Med. 1981, 305, 263-266.

9. Goldsmith, S.R.; Frances, C.G.; Cowley, A.W.; Levine, B.; Cohn, J.N. Increased plasma arginine vasopressin levels in patients with congestive heart failure. J. Am. Coll. Cardiol. 1983, 1, 1385-1390. [CrossRef] 
10. Nakamura, T.; Funayama, H.; Yoshimura, A.; Tsuruya, Y.; Saito, M.; Kawakami, M.; Ishikawa, S. Possible vascular role of increased plasma arginine vasopressin in congestive heart failure. Int. J. Cardiol. 2006, 106, 191-195. [CrossRef] [PubMed]

11. Imamura, T.; Kinugawa, K.; Hatano, M.; Fujino, T.; Inaba, T.; Maki, H.; Kinoshita, O.; Nawata, K.; Kyo, S.; Ono, M.; et al. Low cardiac output stimulates vasopressin release in patients with stage D heart failure. Circ. J. 2014, 78, 2259-2267. [CrossRef] [PubMed]

12. Gines, P.; Arroyo, V.; Rodes, J. Disorders of renal function in cirrhosis: Pathophysiology and clinical aspects. In Hepatology, 3rd ed.; Zakim, D., Boyer, T.D., Eds.; Saunders: Philadelphia, PA, USA, 1996; pp. 650-675.

13. Bichet, D.G.; Szatalowicz, V.; Chaimovitz, C.; Schrier, R.W. Role of vasopressin in abnormal water excretion in cirrhotic patients. Ann. Intern. Med. 1982, 96, 413-417. [CrossRef] [PubMed]

14. Kim, J.K.; Summer, S.; Howard, R.L.; Schrier, R.W. Vasopressin gene expression in rats with experimental cirrhosis. Hepatology 1993, 17, 143-147. [CrossRef] [PubMed]

15. Bichet, B.G.; van Puttan, V.; Schrier, R.W. Potential role of increased sympathetic activity in impaired sodium and water excretion in cirrhosis. N. Engl. J. Med. 1982, 307, 1552-1557. [CrossRef] [PubMed]

16. Schrier, R.W.; Berl, T.; Anderson, R.J. Osmotic and non-osmotic control of vasopressin release. Am. J. Physiol. 1979, 236, F321-F332. [PubMed]

17. Yamashita, T.; Yoshida, M.; Yamada, H.; Asano, T.; Aoki, A.; Ikoma, A.; Kusaka, I.; Kakei, M.; Ishikawa, S. Prompt efficacy of tolvaptan in treating hyponatremia of syndrome of inappropriate secretion of antidiuretic hormone (SIADH) closely associated with rupture of a gastric artery aneurysm. Intern. Med. 2014, 53, 845-849. [CrossRef] [PubMed]

18. Verbalis, J.G.; Drutarosky, M.D. Adaptation to chronic hypoosmolality in rats. Kidney Int. 1988, 34, 351-360. [CrossRef] [PubMed]

19. Fushimi, K.; Uchida, S.; Hara, Y.; Hirata, Y.; Marumo, F.; Sasaki, S. Cloning and expression of apical membrane water channel of rat kidney collecting tubule. Nature 1993, 361, 549-552. [CrossRef] [PubMed]

20. Fujita, N.; Ishikawa, S.; Sasaki, S.; Fujisawa, G.; Fushimi, K.; Marumo, F.; Saito, T. Role of water channel AQP-CD in water retention in SIADH and cirrhotic rats. Am. J. Physiol. 1995, 269, F926-F931. [PubMed]

21. Saito, T.; Higashiyama, M.; Nagasaka, S.; Sasaki, S.; Saito, T.; Ishikawa, S. Role of aquaporin-2 gene expression in hyponatremic rats with chronic vasopressin-induced antidiuresis. Kidney Int. 2001, 60, 1266-1276. [CrossRef] [PubMed]

22. Xu, D.L.; Martin, P.Y.; Ohara, M.; StJohn, J.; Pattison, T.; Meng, X.; Morris, K.; Kim, J.K.; Schrier, R.W. Upregulation of aquaporin-2 water channel expression in chronic heart failure rat. J. Clin. Investig. 1997, 99, 1500-1505. [CrossRef] [PubMed]

23. Nielsen, S.; Terris, J.; Anderson, D.; Ecelbarger, C.; Froklaer, J.; Jonassen, T.; Marples, D.; Knepper, M.A.; Petersen, J.S. Congestive heart failure in rats is associated with increased expression and targeting of aquaporin-2 water channel in collecting duct. Proc. Natl. Acad. Sci. USA 1997, 94, 5450-5455. [CrossRef] [PubMed]

24. Saito, T.; Saito, T.; Kasono, K.; Tamemoto, H.; Kawakami, M.; Sasaki, S.; Ishikawa, S. Hypotonicity reduces the activity of murine aquaporin-2 promoter induced by dibutyryl cAMP. Exp. Physiol. 2008, 93, 1147-1156. [CrossRef] [PubMed]

25. Kanno, K.; Sasaki, S.; Hirata, Y.; Ishikawa, S.; Fushimi, K.; Nakanishi, S.; Bichet, D.G.; Marumo, F. Urinary excretion of aquaporin-2 in patients with diabetes insipidus. N. Engl. J. Med. 1995, 332, 1540-1545. [CrossRef] [PubMed]

26. Saito, T.; Ishikawa, S.; Sasaki, S.; Nakamura, T.; Rokkaku, K.; Kawakami, A.; Honda, K.; Saito, T. Urinary excretion of aquaporin-2 in the diagnosis of central diabetes insipidus. J. Clin. Endocrinol. Metab. 1997, 82, 1823-1827. [CrossRef] [PubMed]

27. Sasaki, S.; Ohmoto, Y.; Mori, T.; Iwata, F.; Muraguchi, M. Daily variance of urinary excretion of AQP2 determined by sandwich ELISA method. Clin. Exp. Nephrol. 2012, 16, 406-410. [CrossRef] [PubMed]

28. Rai, T.; Sekine, K.; Kanno, K.; Hata, K.; Miura, M.; Mizushima, A.; Marumo, F.; Sasaki, S. Urinary excretion of aquaporin-2 water channel in human and rat. J. Am. Soc. Nephrol. 1997, 8, 1357-1362. [PubMed]

29. Saito, T.; Ishikawa, S.; Ando, F.; Okada, N.; Nakamura, T.; Kusaka, I.; Higashiyama, M.; Nagasaka, S.; Saito, T. Exaggerated urinary excretion of aquaporin-2 in the pathological state of impaired water excretion dependent upon arginine vasopressin. J. Clin. Endocrinol. Metab. 1998, 83, 4034-4040. [CrossRef] [PubMed] 
30. Funayama, H.; Nakamura, T.; Saito, T.; Yoshimura, A.; Saito, M.; Kawakami, M.; Ishikawa, S. Urinary excretion of aquaporin-2 water channel exaggerated dependent upon vasopressin in congestive heart failure. Kidney Int. 2004, 66, 1387-1392. [CrossRef] [PubMed]

31. Gheroghiade, M.; Abraham, W.T.; Albert, N.M.; Gattis-Stough, W.; Greenberg, B.H.; O'Connor, C.M.; She, L.; Yancy, C.W.; Young, J.; Fonarow, G.C.; et al. Relationship between admission serum sodium concentration and clinical outcomes in patients hospitalized for heart failure: An analysis from the OPTIMIZE-HF registry. Eur. Heart J. 2007, 28, 980-988. [CrossRef] [PubMed]

32. Arao, K.; Fujiwara, T.; Sakakura, K.; Wada, H.; Sugawara, Y.; Suga, C.; Ako, J.; Ishikawa, S.; Momomura, S. Hyponatremia for worsening heart failure in patients receiving cardiac resynchronization therapy. Circ. J. 2013, 77, 116-122. [CrossRef] [PubMed]

33. Klein, L.; O'Connor, C.M.; Leimberger, J.O.; Gattis-Stough, W.; Pina, I.L.; Felker, G.M.; Adams, K.F.; Califf, R.M.; Gheroghiade, M.; OPTIMIZE-CHF Investigators. Low serum sodium is associated with increased short-term mortality in hospitalized patients with worsening heart failure. Results from the Outcomes of a Prospective Trial of Intravenous Milrinone for Exacerbations of Chronic Heart Failure (OPTIMIZE-CHF) study. Circulation 2005, 111, 2454-2460. [PubMed]

34. Gheroghiade, M.; Rossi, J.S.; Cotts, W.; Shin, D.O.; Hellkamp, A.S.; Pina, I.L.; Fonarow, G.C.; DeMarco, T.; Pauly, D.F.; Rogers, J. Characterization and prognostic value of persistent hyponatremia in patients with severe heart failure in the ESCAPE Trial. Arch. Intern. Med. 2007, 167, 1998-2005. [CrossRef] [PubMed]

35. Ishikawa, S. Arginine vasopressin in heart failure. Circ. J. 2014, 78, 2159-2161. [CrossRef] [PubMed]

36. Cardenas, A.; Gines, P. Predicting mortality in cirrhosis: Serum sodium helps. N. Engl. J. Med. 2008, 359, 1060-1062. [CrossRef] [PubMed]

37. Guevara, M.; Baccaro, M.E.; Torre, A.; Gomez-Anson, B.; Rios, J.; Torres, F.; Rami, L.; Monte-Rubio, G.C.; Martin-Llahi, M.; Arroyo, V.; et al. Hyponatremia is a risk factor of hepatic encephalopathy in patients with cirrhosis: A prospective study with time-dependent analysis. Am. J. Gastroenterol. 2009, 104, 1382-1389. [CrossRef] [PubMed]

38. Jenq, C.C.; Tsai, M.H.; Tian, Y.C.; Chang, M.Y.; Lin, C.Y.; Lien, C.M.; Chen, Y.C.; Fang, J.T.; Chen, P.C.; Yang, C.W. Serum sodium predicts prognosis in critically ill cirrhotic patients. J. Clin. Gastroenterol. 2010, 44, 220-226. [CrossRef] [PubMed]

39. Yamamura, Y.; Ogawa, H.; Yamashita, H.; Chihara, T.; Miyamoto, H.; Nakamura, S.; Onogawa, T.; Yamashita, T.; Hosokawa, T.; Mori, T.; et al. Characterization of a novel aquaretic agent, OPC-31260, as an orally effective, nonpeptide vasopressin $V_{2}$ receptor antagonist. Br. J. Pharmacol. 1992, 105, 787-791. [CrossRef] [PubMed]

40. Yamamura, Y.; Nakamura, T.; Itoh, J.; Hirano, T.; Onogawa, T.; Yamashita, T.; Yamada, Y.; Tsujimae, K.; Aoyama, M.; Kotosai, K.; et al. OPC-41061, a highly potent human vasopressin $\mathrm{V}_{2}$-receptor antagonist: Pharmacological profile and aquaretic effect by single and multiple oral dosing in rats. J. Pharmacol. Exp. Ther. 1998, 287, 860-866. [PubMed]

41. Fujisawa, G.; Ishikawa, S.; Tsuboi, Y.; Okada, K.; Saito, T. Therapeutic efficacy of non-peptide ADH antagonist OPC-31260 in SIADH rats. Kidney Int. 1993, 44, 19-23. [CrossRef] [PubMed]

42. Tsuboi, Y.; Ishikawa, S.; Fujisawa, G.; Okada, K.; Saito, T. Therapeutic efficacy of the non-peptide AVP antagonist OPC-31260 in cirrhotic rats. Kidney Int. 1994, 46, 237-244. [CrossRef] [PubMed]

43. Saito, T.; Ishikawa, S.; Abe, K.; Kamoi, K.; Yamada, K.; Shimizu, K.; Saruta, T.; Yoshida, S. Acute aquaresis by the nonpeptide arginine vasopressin (AVP) antagonist OPC-31260 improves hyponatremia in patients with syndrome of inappropriate secretion of antidiuretic hormone (SIADH). J. Clin. Endocrinol. Metab. 1997, 82, 1054-1057. [CrossRef] [PubMed]

44. Berl, T.; Quittant-Pelletier, F.; Verbalis, J.G.; Schrier, R.W.; Bichet, D.G.; Ouyang, J.; Czerwiec, F.S. Oral tolvaptan is safe and effective in chronic hyponatremia. J. Am. Soc. Nephrol. 2010, 21, 705-712. [CrossRef] [PubMed]

45. Gheroghiade, M.; Niazi, I.; Ouyang, J.; Czerwiec, F.; Kambayashi, J.; Zampino, M.; Otlandi, C. Vasopressin $\mathrm{V}_{2}$-receptor blockade with tolvaptan in patients with chronic heart failure: Results from a double-blind, randomized trial. Circulation 2003, 107, 2690-2696. [CrossRef] [PubMed]

46. Gheroghiade, M.; Konstam, M.A.; Burnett, J.C.; Grinfeld, L.; Maggioni, A.P.; Swedberg, K.; Udelson, J.E.; Zannad, F.; Cook, T.; Ouyang, J.; et al. Short-term clinical effects of tolvaptan, an oral vasopressin antagonist, in patients hospitalized for heart failure. The EVEREST clinical status trial. JAMA 2007, 297, 1332-1343. [CrossRef] [PubMed] 
47. Kinugawa, K.; Sato, N.; Inomata, T.; Shimokawa, Y.; Iwatake, N.; Mizuguchi, K. Efficacy and safety of tolvaptan in heart failure patients with volume overload: An interim result of post-marketing surveillance in Japan. Circ. J. 2014, 78, 844-852. [CrossRef] [PubMed]

48. Imamura, T.; Kinugawa, K.; Shiga, T.; Kato, N.; Muraoka, H.; Minatsuki, S.; Inaba, T.; Maki, H.; Hatano, M.; Yao, A.; et al. Novel criteria of urinary osmolality effectively predict response to tolvaptan in decompensated heart failure patients: Association between non-responders and chronic kidney disease. Circ. J. 2013, 77, 397-404. [CrossRef] [PubMed]

49. Toda, H.; Nakamura, K.; Nakahama, M.; Wada, T.; Watanabe, A.; Hashimoto, K.; Terasaka, R.; Tokioka, K.; Nishii, N.; Miyoshi, T.; et al. Clinical characteristics of responders to treatment with tolvaptan in patients with acute decompensated heart failure: Importance of preserved kidney size. J. Cardiol. 2016, 67, 177-183. [CrossRef] [PubMed]

50. Uemura, Y.; Shibata, R.; Takemoto, K.; Uchikawa, T.; Koyasu, M.; Ishikawa, S.; Imai, R.; Ozaki, Y.; Watanabe, S.; Teraoka, T.; et al. Safety and efficacy of long-term use of tolvaptan in patients with heart failure and chronic kidney disease. Circ. J. 2017. [CrossRef] [PubMed]

51. Matsue, Y.; Suzuki, M.; Torii, S.; Yamaguchi, S.; Fukamizu, S.; Ono, Y.; Fujii, H.; Kitai, T.; Nishioka, T.; Sugi, K.; et al. Prognostic impact of early treatment with tolvaptan in patients with acute heart failure and renal dysfunction. Int. J. Cardiol. 2016, 221, 188-193. [CrossRef] [PubMed]

52. Gaglio, P.; Marfo, K.; Chiodo, J. Hyponatremia in cirrhosis and end-stage liver disease: Treatment with the vasopressin $\mathrm{V}_{2}$-receptor antagonist tolvaptan. Dig. Dis. Sci. 2012, 57, 2774-2785. [CrossRef] [PubMed]

53. Cardenas, A.; Gines, P.; Marotta, P.; Czewiec, F.; Ouyang, J.; Guevara, M.; Afdhal, N.H. Tolvaptan, an oral vasopressin antagonist, in the treatment of hyponatremia in cirrhosis. J. Hepatol. 2012, 56, 571-578. [CrossRef] [PubMed]

54. Sakaida, I.; Kawazoe, S.; Kajimura, K.; Saito, T.; Okuse, C.; Takaguchi, K.; Okada, M.; Okita, K.; The ASCITES-DOUBLEBLIND Study Group. Tolvaptan for improvement of hepatic edema: A phase 3, multicenter, randomized, double-blind, placebo-controlled trial. Hepatol. Res. 2014, 44, 73-82. [CrossRef] [PubMed]

(C) 2017 by the author. Licensee MDPI, Basel, Switzerland. This article is an open access article distributed under the terms and conditions of the Creative Commons Attribution (CC BY) license (http://creativecommons.org/licenses/by/4.0/). 